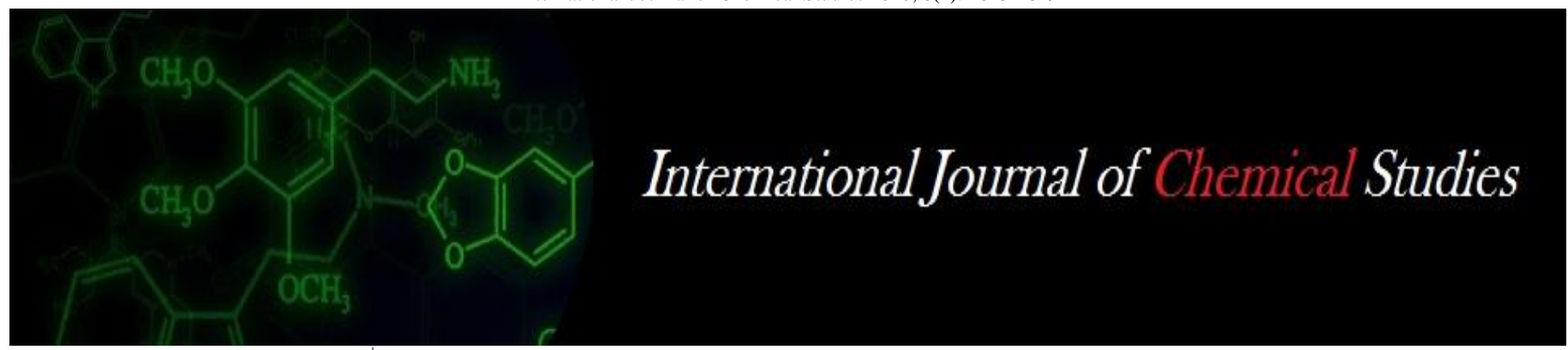

P-ISSN: 2349-8528

E-ISSN: 2321-4902

IJCS 2020; 8(1): 1845-1849

(C) 2020 IJCS

Received: 13-11-2019

Accepted: 15-12-2019

Mehjabeen

Research Scholar, Department of Soil Science and Agricultural

Chemistry, Bihar Agricultural

University, Sabour, Bihar, India

Anoop Kumar Dwiwedi

Research Scholar, Department of

Agronomy, Institute of

Agricultural Sciences, Banaras

Hindu University, Varanasi,

Uttar Pradesh, India

Deepranjan Sarkar

Research Scholar, Department of

Soil Science and Agricultural

Chemistry, Institute of

Agricultural Sciences, Banaras

Hindu University, Varanasi,

Uttar Pradesh, India

\section{A Rakshit}

Assistant Professor, Department of Soil Science and Agricultural Chemistry, Institute of

Agricultural Sciences, Banaras

Hindu University, Varanasi,

Uttar Pradesh, India
Corresponding Author:

Mehjabeen

Research Scholar, Department of

Soil Science and Agricultural

Chemistry, Bihar Agricultural

University, Sabour, Bihar, India

\section{Seed biopriming with Trichoderma improves yield of Rajmash (Phaseolus vulgaris C.V. HUR-137) in Varanasi region of Uttar Pradesh}

\author{
Mehjabeen, Anoop Kumar Dwiwedi, Deepranjan Sarkar and A Rakshit
}

DOI: https://doi.org/10.22271/chemi.2020.v8.i1aa.8532

\begin{abstract}
Plants of red kidney bean (Phaseolus vulgaris) were treated with different grades of recommended dose of fertilizer along with biopriming with Trichoderma harzianum. The treatment along with the inorganic fertilizer treatment was applied as an attempt to enhance the yield through the microbial agent Trichoderma. Treatment of red kidney bean seeds were treated with the Trichoderma isolates using powder (talc) formulation to promote growth and development of the bean plants in greenhouse conditions. Among the treatments the plants treated with full dose of fertilizer without any bio-treatments was found the best as per growth and development but the bean plants treated with inorganic fertilizers at $90 \%$ dose combined with biopriming was comparable and suggests that the use of bio-agents can be used significantly to improve the yield and growth of the crops which is reduced as a part of the treatments. Also, the bean plants treated solely with the bio-agent represented a very good rhizospheric growth without the use of any kind of inorganic inputs. The treatments bioprimed with Trichoderma showed a good growth despite a lower dose of nutrient applied.
\end{abstract}

Keywords: Bio-priming, yield, dry matter production, height, red kidney bean

\section{Introduction}

Common bean (Phaseolus vulgaris L.; $2 \mathrm{n}=2 \mathrm{x}=22$ ) is a predominantly self-pollinated crop originated mainly in Latin America and spread to other parts of world and now it is widely cultivated in the tropics and subtropics as well as in temperate regions of the world (Gepts and Bliss 1988; Zeven 1997, 1999; Kumar et al, 2008) ${ }^{[4,15,6]}$. In India, common bean is known by the names like 'Rajmash' and 'Frash bean (green bean)' and grows in certain parts of the country. Common bean production in India is 4,340 million tones as compared 18,943 million tons in the world. (Anonymous, 2003; Kumar et al, 2008) ${ }^{[1,6]}$.

Bio-priming is a new technique of seed treatment that integrates biological (inoculation of seed with beneficial organism to protect seed) and physiological aspects (seed hydration) of disease control. Biopriming using naturally occurring soil microorganisms is a safe, non-polluting, and environmentally sound disease control measure and an effective pre-sowing seed treatment. There are some known beneficial bacteria and fungi which, if applied to seed prior to planting, may enhance plant growth and development. Biopriming allows rapid colonization of the beneficial organism on the seed, and often results in a more uniform coverage of the seed surface compared to other priming techniques (Smith, 1996; Warren and Bennett, 1997) ${ }^{[10,12]}$. Biopriming is a common practice in the seed industry worldwide. During the seed coating process, inoculants, fungicides, or insecticides are added together with other substances, which provide a protective barrier on the seed. Biopriming has been shown to be more effective than regular chemical treatment for disease control (Ashraf and Foolad, 2005) ${ }^{[2]}$. Seed are coated with bacteria and soaked in warm water until their moisture content rises to $35-40 \%$, the term "biopriming" is used.

The stem diameter, root and foliar dry weight parameters suggested a positive effect of $T$. koningiopsis Th003 on tomato growth response after transplant as well. These results are in agreement with an early report in cucumber plants inoculated with T. harzianum T-203 (Moreno et al, 2009). The shoot fresh and dry weight as well as yield was enhanced by nonautoclaved Trichoderma WT inocula applied at $1 \%$ and produced with a fermentation time of 
6 or 12 days in lettuce (Ousley et al, 2013). Bioagents Trichoderma enhance the seed treatment on germination and vigour in chick pea (Kumar et al, 2014) ${ }^{[5]}$. Single inoculations of common dry bean with selected Trichoderma species have been reported to increase plant dry growth and height (Yobo et al, 2009) ${ }^{[14]}$. Biopriming of chickpea and rajma seeds with Trichoderma, Pseudomonas and Rhizobium showed increased seed germination and accumulation of biomass in both the crops under both pot and field conditions (Yadav et al, 2013) ${ }^{[13]}$. Trichoderma isolates increases the height, dry weight and yield of plants as it is known to produce plant hormones like auxin, gibberellins and other volatile compounds (Contreras-Cornejo et al, 2009; Vinale et al, 2008) ${ }^{[3,11]}$

\section{Materials and Methods}

The pot experiment was conducted during Rabi season of 2016-2017 in the net house of Department of Soil Science and Agricultural Chemistry, Institute of Agricultural Sciences, B.H.U. Varanasi, U.P.

To conduct the pot experiment, bulk surface $(0-15 \mathrm{~cm})$ soil was collected from the Agricultural Research Farm, Institute of Agricultural Sciences, Banaras Hindu University, and Varanasi. The soils of Varanasi are formed on alluvium deposited by the river Ganges and have predominance of illite, quartz and feldspars minerals. The alluvial soil is characterized by higher silt content. Illicit nature of alluvial sediments is clearly demonstrated by higher $\mathrm{K}_{2} \mathrm{O}$ content. The cropping history of the site from where the soil was collected is the rice-wheat. The fertility status of the soil can be included as low to medium with a slightly alkaline reaction.

After collecting the soil, it was sieved and $10 \mathrm{~kg}$ of soil was filled in each polythene lined earthern pot.

\section{Crop and variety \\ Crop: Kidney Bean \\ Scientific name: Phaseolus vulgaris \\ Family: Fabaceae \\ Variety: HUR-137}

Seeds of red kidney beans were first soaked in sodium hypochlorite solution for one minute. Rinse with sterilized water 4-5 times and kept for air drying or in laminar air flow. Spores of Trichoderma harzianum were collected in vials by adding $4-5 \mathrm{ml}$ of $0.85 \%$ saline water in the petri plate. In petri plate, autoclaved filter paper were spread and dried. Per treatment 50 seeds were taken in the petri plates. Then the microbial suspension were spread uniformly over seeds and kept for drying.

\section{Experimental Details}

The experiment has been under taken on alluvial soil at the Institute of Agricultural Sciences, Banaras Hindu University, during November 2016 to March 2017, under net-house conditions, bioprimed seed of kidney bean with microbial consortium along with different levels recommended fertilizer doses was grown. Weeding was done as soon as weeds emerge. Irrigation is given as per requirement of crop that keep soil moist throughout growth period. Fertilizers applied in recommended dose N: P: K @ 120: 60: 60 kg/ha, 1/2th N, Full $\mathrm{P} \& \mathrm{~K}$ given at time of sowing and rest $\mathrm{N}$ given in 2 split dose at 25 DAS and 45 DAS. Pods were harvested after they were fully matured. The experimental design was an experiment under completely randomized block design with three replications (CRD).
Table 1: Details of treatment

\begin{tabular}{|c|c|c|}
\hline Treatment & Fertilizer dose & $\begin{array}{c}\text { Microbe used in seed } \\
\text { treatment }\end{array}$ \\
\hline T1 & Control N: P: K @ 0:0:0 kg/ha & No \\
\hline T2 & $\begin{array}{c}100 \% \text { of RDF N: P: K @ 180: } \\
60: 60 \mathrm{~kg} / \mathrm{ha}\end{array}$ & No \\
\hline T3 & $70 \%$ OF RDF & Trichoderma harzianum \\
\hline T4 & $80 \%$ OF RDF & Trichoderma harzianum \\
\hline T5 & $90 \%$ OF RDF & Trichoderma harzianum \\
\hline T6 & N: P: K @ 0:0:0 kg/ha & Trichoderma harzianum \\
\hline
\end{tabular}

First of all the total experimental pots were divided into three blocks. Each block was divided into 3 units containing 9 pots and each having 2 plants. So there were total 54 experimental units.

\section{Physicochemical properties of soil}

Physico-chemical properties of soil determined for alluvial soil. From the table it is evident that bulk density of soil was 1.39 $\mathrm{Mg} \mathrm{m}^{-3}$. The experimental soil was sandy loam in texture. The soil is almost neutral in reaction. The soil has low organic matter content. EC varied from $0.44 \mathrm{dSm}^{-1}$, CEC from $28.98 \mathrm{C} \mathrm{mol}\left(\mathrm{p}^{+}\right) / \mathrm{kg}$, available N $229 \mathrm{~kg} / \mathrm{ha}, \mathrm{P} 17 \mathrm{~kg} / \mathrm{ha}$, $\mathrm{K} 230 \mathrm{~kg} / \mathrm{ha}$.

Table 2: Physicochemical properties of experimental soil

\begin{tabular}{|c|c|}
\hline Physical Parameter & Alluvial Soil \\
\hline Bulk Density $\left(\mathrm{Mg} \mathrm{m}^{-3}\right)$ & 1.39 \\
\hline Particle density $\left(\mathrm{Mg} \mathrm{m}^{-3}\right)$ & 2.56 \\
\hline Water holding capacity (\%) & 39.9 \\
\hline Sand $(\%)$ & 48.78 \\
\hline Silt $(\%)$ & 30.48 \\
\hline Clay $(\%)$ & 20.44 \\
\hline Soil Texture & Sandy loam \\
\hline $\mathrm{pH}(1: 2.5)$ & 7.2 \\
\hline $\mathrm{EC}(\mathrm{dS} / \mathrm{m})$ & 0.44 \\
\hline $\mathrm{CEC}\left(\mathrm{C} \mathrm{mol}\left(\mathrm{p}^{+}\right) / \mathrm{kg}\right)$ & 28.98 \\
\hline Organic carbon $(\%)$ & 0.37 \\
\hline Available N (kg/ha) & 229 \\
\hline Available $\mathrm{P}(\mathrm{kg} / \mathrm{ha})$ & 17 \\
\hline Available K $(\mathrm{kg} / \mathrm{ha})$ & 230 \\
\hline Available $\mathrm{Zn}(\mathrm{ppm})$ & 0.15 \\
\hline
\end{tabular}

For Dry weight of plants, after harvesting plant samples were kept in paper bags and dried in hot air oven at $60 \pm 2{ }^{\circ} \mathrm{C}$ till the constant weight. For Yield attribute each pod was selected from every pot were weighed by electronic balance. Yield/pot was recorded after harvesting of crop. Regarding Statistical analysis Duncan multiple range analysis was done through software STAR.

\section{Results and Discussion Plant Height}

Data on plant height as affected by different treatments, recorded at 30,60 and 90 days after sowing are presented in table-3 and depicted graphically in figure-1.Observations reveal that shoot elongation continued to increase with the advancement of crop growth stages. Slow increase in plant height was noted during early stages of growth up to 30 DAS. Rate of elongation was higher in between 60 to 90 DAS. Among the treatments $T_{2}$ gave the maximum plant height of red kidney bean. Increasing levels of NPK fertilizers up to RDF of N: P: K @ 100: 60: $25 \mathrm{~kg} / \mathrm{ha}\left(\mathrm{T}_{2}\right)$ gave maximum enhancement of plant height at all the stages of crop growth as compared to other treatments. Reduction in NPK levels i.e. $90 \%, 80 \%$ and $70 \%$ RDF significantly decreased the plant 
height. It is clearly evident that application of RDF of N: P: K @ 100: 60: $25 \mathrm{~kg} / \mathrm{ha}\left(\mathrm{T}_{2}\right)$ significantly produced highest plant height at all growth stages of red kidney bean in comparison to lower doses of N:P:K addition. Among the treatments at 30 DAS, $T_{2}$ caused significantly higher plant height and this treatment was significantly superior over rest of the treatments. At 60 DAS significantly higher plant height was recorded with treatment $\mathrm{T}_{2}(36.825 \mathrm{~cm}, \mathrm{RDF}$ of $\mathrm{N}: \mathrm{P}: \mathrm{K}$ @ 100: 60: $25 \mathrm{~kg} / \mathrm{ha}$ ) which is at par with $\mathrm{T}_{5}$ and $\mathrm{T}_{6}$ followed by $\mathrm{T}_{5}$ (seed treatment with $T$. harzianum $+90 \%$ RDF of N:P: $\mathrm{K}), \mathrm{T}_{4}$ (seed treatment with $T$. harzianum $+80 \%$ RDF of $\mathrm{N}: \mathrm{P}$ : $\mathrm{K}), \mathrm{T}_{3}$ (seed treatment with $T$. harzianum $+70 \%$ RDF of $\mathrm{N}: \mathrm{P}$ : $\mathrm{K}), \mathrm{T}_{6}$ (seed treatment with $T$. harzianum $+\mathrm{RDF}$ of N: P: K @ 0:0:0 kg/ha) and $\mathrm{T}_{1}$ (control N: P: K @ 0:0:0 kg/ha). However, at 90 DAS significantly plant height was recorded with the treatment $T_{2}(35.675 \mathrm{~cm})$ which is at par with $T_{5}$, this was significantly superior than rest of the treatments. Significantly lower plant height was recorded with $\mathrm{T}_{1}$ (control N:P: K @0:0:0 kg/ha).
At 90 DAS plant height ranged between, 36.33 to 63.00 and 44.50 to $47.12 \mathrm{~cm}$ in different treatments. In case of effect of T. harzianum and different graded dose of NPK application, plant height was recorded in following order: $T_{2}>T_{5}>T_{4}$ $>T_{3}>T_{6}>T_{1}$ in all the growth stages of red kidney bean.

Result clearly illustrated that plant height of red kidney bean was boosted by the combined use of Trichoderma harzianum and N: P: K. The increase in plant height may be due to increased nutrient availability by root elongation and plant growth promoting activities by Trichoderma harzianum. It may also be ascribed due to adequate supply of nutrients due to mineralization of nutrients by increased population of Trichoderma harzianum. Enhanced plant height by Trichoderma may be due to production of secondary metabolites which may act as an auxin compound and other secondary metabolites such as harzianolide and, anthraquinone. Similar results also reported by Vinale et al. (2008) ${ }^{[11]}$ in wheat, Molla et al. (2012) ${ }^{[7]}$.

Table 3: Effect of biopriming with T. harzianum and graded dose of N: P: K application on plant height (cm) of red kidney bean at different growth stages and yield $\left(\mathrm{g} \mathrm{pot}^{-1}\right)$

\begin{tabular}{|c|c|c|c|c|}
\hline Treatment & Vegetative stage & Pod formation & Maturation stage & Yield/pot(g) \\
\hline T1:Control & $9.875 \mathrm{a}$ & $29.175 \mathrm{a}$ & $31 \mathrm{a}$ & $23.98 \mathrm{c}$ \\
\hline T2:RDF & $13.675 \mathrm{c}$ & $36.825 \mathrm{c}$ & $35.675 \mathrm{~b}$ & $86.48 \mathrm{a}$ \\
\hline T3:70\% RDF+ Biopriming & $12.525 \mathrm{bc}$ & $31.95 \mathrm{ab}$ & $32.675 \mathrm{a}$ & $40.92 \mathrm{bc}$ \\
\hline T4: 80\% RDF+ Biopriming & $12.95 \mathrm{bc}$ & $33.675 \mathrm{abc}$ & $33 \mathrm{a}$ & $49.31 \mathrm{~b}$ \\
\hline T5:90RDF+ Biopriming & $13.525 \mathrm{c}$ & $36.175 \mathrm{bc}$ & $33.675 \mathrm{ab}$ & $55.39 \mathrm{~b}$ \\
\hline T6:Control+ Biopriming & $11.575 \mathrm{ab}$ & $29.575 \mathrm{a}$ & $31.75 \mathrm{a}$ & $32.87 \mathrm{bc}$ \\
\hline
\end{tabular}

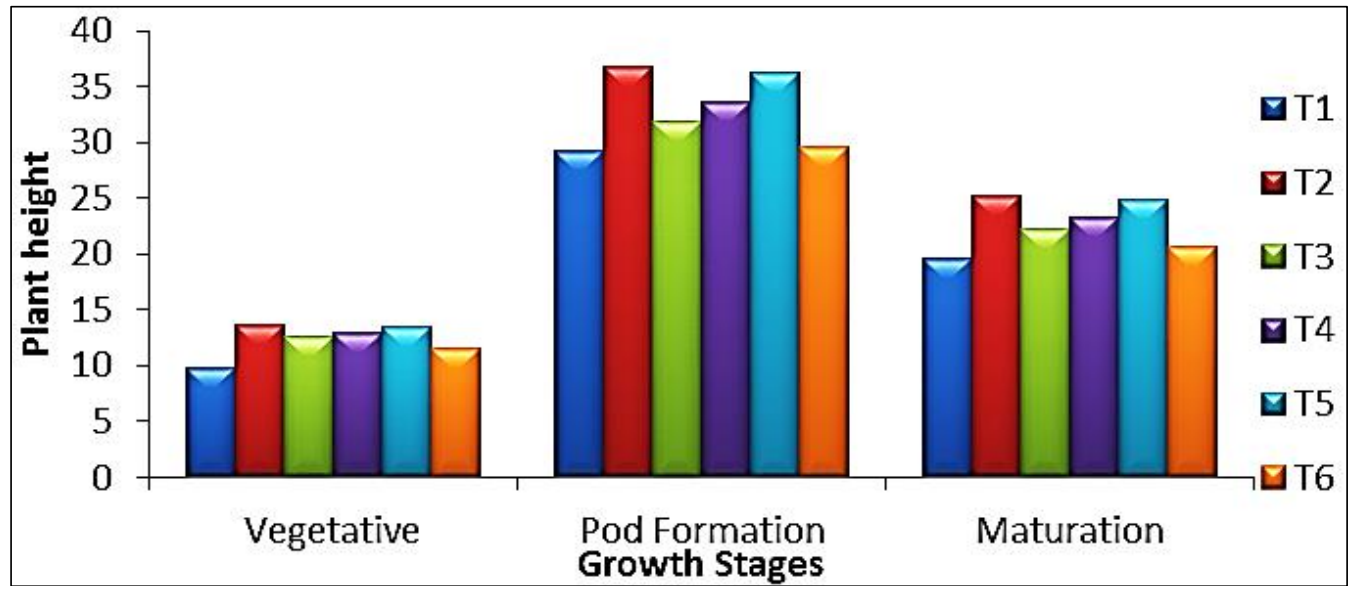

Fig 1: Effect of biopriming with T. harzianum and graded dose of N: P: K application on plant height (cm) of red kidney bean at different growth stage

( $\mathrm{T}_{1}$ : Control N: P: K @ 0:0:0 kg/ha, $\mathrm{T}_{2}: \mathrm{RDF}$ of $\mathrm{N}: \mathrm{P}: \mathrm{K}$ @ 100: 60: $25 \mathrm{~kg} / \mathrm{ha}, \mathrm{T}_{3}$ : Seed treatment with T. harzianum + $70 \% \mathrm{~N}$ and RDF of N: P: K, $\mathrm{T}_{4}$ : Seed treatment with $T$. harzianum $+80 \%$ RDF of N: P: K, $\mathrm{T}_{5}$ : Seed treatment with $T$. harzianum $+90 \%$ RDF of $\mathrm{N}: \mathrm{P}: \mathrm{K}$ and $\mathrm{T}_{6}$ : Seed treatment with T. harzianum ; DAS-Days after Sowing; RDF-Recommended dose of fertilizer)

\section{Yield of red kidney bean}

The effects of Trichoderma harzianum and soils type with graded dose of nitrogen application significantly influenced grain yield and are shown in table-4 and graphically represented in figure-2. Significant yield increases due to different treatment combinations were observed. All the treatments with graded NPK application along with seed biopriming with Trichoderma harzianum significantly increased grain yield of red kidney bean. Significantly maximum grain yield was recorded with $\mathrm{T}_{2}\left(86.48 \mathrm{~g} \mathrm{pot}^{-1}\right)$ (RDF of N: P: K @ 100: 60: $25 \mathrm{~kg} / \mathrm{ha}$ ) followed by the treatments $\mathrm{T}_{5}\left(55.39 \mathrm{~g} \mathrm{pot}^{-1}\right), \mathrm{T}_{4}\left(49.31 \mathrm{~g} \mathrm{pot}^{-1}\right), \mathrm{T}_{3}(40.92 \mathrm{~g}$ pot $\left.^{-1}\right), \mathrm{T}_{6}\left(32.87 \mathrm{~g} \mathrm{pot}^{-1}\right)$ and $\mathrm{T}_{1}\left(23.98 \mathrm{~g} \mathrm{pot}^{-1}\right)$ i.e. control. Grain yield of rajmash ranged from 23.98 to $86.48 \mathrm{~g} \mathrm{plant}^{-1}$. Increase in grain yield by $62.50 \mathrm{~g} \mathrm{plant}^{-1}$ in $\mathrm{T}_{2}$ (RDF of $\mathrm{N}$ : P: $\mathrm{K}$ @ 100: 60: $25 \mathrm{~kg} / \mathrm{ha}$ ) over $\mathrm{T}_{1}$ (Control 0:0:0 N and RDF of $\mathrm{P}: \mathrm{K})$ have been demonstrated. $\mathrm{T}_{2}$ with maximum yield is statistically different from rest all the treatments. One of the good yielding treatment i.e. $\mathrm{T}_{5}$ is statistically different from $\mathrm{T}_{1}$, similar to $\mathrm{T}_{4}$ while at par with $\mathrm{T}_{3}$ and $\mathrm{T}_{6}$. The increase in grain yield may be due to steady and slow release of nutrients to the plants (Figure 2). 


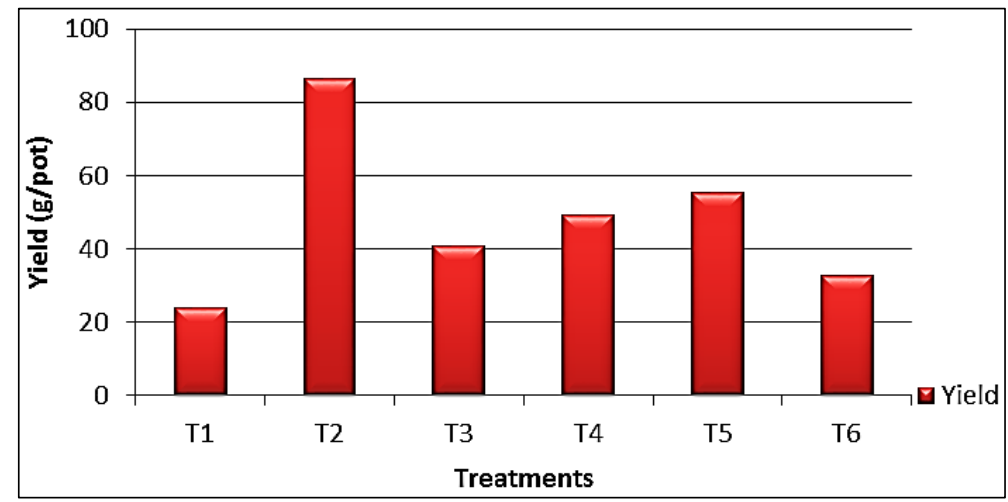

Fig 2: Effect of biopriming with T. harzianum and graded levels of $\mathrm{N}$ application on yield of red kidney bean

The overall result revealed that priming of red kidney bean seeds with inoculants of Trichoderma along with $90 \%$ RDF application gave better performance in all respect of yield and bio-control potential as compared to control and others and emerged as an alternative to full dose of RDF. These findings are in accordance with number of researchers (Geraldine et al., 2013; Verma et al., 2014) [16, 17] observations: under varied agro-ecological niche.

\section{Dry matter production}

The data on dry matter production (DMP) are given in table 5 and depicted graphically in figure-3. The experimental results revealed that almost a consistent increase in the DMP occurred with the advancement of the crop growth stages and reaching the maximum at the maturity.

The rate of increase in DMP was enhanced rapidly between 30 to 60 DAS. It is clearly evident that application of RDF of N: P: K @ 100: 60: 25 kg/ha $\left(\mathrm{T}_{2}\right)$ produced lucidly higher $\mathrm{DMP} /$ plant than lower doses at all the growth stages. Among the treatments at $30 \mathrm{DAS}, \mathrm{T}_{2}$ caused significantly higher dry matter production $\left(0.225 \mathrm{~g}_{\text {plant }}{ }^{-1}\right)$ and this was significant over rest other treatments. $T_{2}$ had maximum dry matter production which is significantly different from $\mathrm{T}_{6}$ and at par with treatments $\mathrm{T}_{5}, \mathrm{~T}_{4}$ and $\mathrm{T}_{3} . \mathrm{T}_{1}$ had minimum dry matter production with $0.122 \mathrm{~g} \mathrm{plant}^{-1}$.
At 60 DAS significantly higher dry matter production was recorded in treatment $\mathrm{T}_{2}\left(0.3067 \mathrm{~g}_{\text {plant }}{ }^{-1}\right.$, RDF of N: P: K @ 100: $50: 25 \mathrm{~kg} / \mathrm{ha}$ ) which is significantly different from $\mathrm{T}_{6}$ and $\mathrm{T}_{3}$ while at par with $\mathrm{T}_{4}$ and $\mathrm{T}_{5}$. Dry matter production followed by $\mathrm{T}_{5}$ (seed treatment with $T$. harzianum $+90 \% \mathrm{~N}$ and $\mathrm{RDF}$ of $\mathrm{P}: \mathrm{K}$ ), $\mathrm{T}_{4}$ (seed treatment with $T$. harzianum $+80 \% \mathrm{~N}$ and $\mathrm{RDF}$ of $\mathrm{P}: \mathrm{K}), \mathrm{T}_{3}$ (seed treatment with $T$. harzianum $+70 \% \mathrm{~N}$ and RDF of $\mathrm{P}: \mathrm{K}), \mathrm{T}_{6}$ seed treatment with T. harzianum+ N: P: K @ 0:0:0 kg/ha and $\mathrm{T}_{1}$ (control N: P: K @ 0:0:0 kg/ha). At 90 DAS the dry matter production increased as compared to 30 to 60 DAS and the significantly higher dry matter production was recorded with the treatment $\mathrm{T}_{2}\left(1.425 \mathrm{~g} \mathrm{plant}^{-1}\right)$ which is statistically different from all other treatments but at par with $\mathrm{T}_{5}\left(1.277 \mathrm{~g}\right.$ plant $\left.^{-1}\right)$ and was significantly higher than rest of the treatments. Lowest dry matter production was recorded with $\mathrm{T}_{1}$ (control $\mathrm{N}$ : P: K @ 0:0:0 kg/ha). At 90 DAS dry matter production ranged between $1.0175,1.425,1.1275,1.21,1.2775$ and 1.21 g plant $^{-}$ ${ }^{1}$ respectively in different treatments.

Result clearly illustrated that dry matter production of red kidney bean plant was boosted by the combined use of Trichoderma harzianum and N: P: K. The increase in dry matter of shoot may be due to increased root dry matter enabling large volume of soil exploitation of the plant which could increase the chance for nutrients uptake through maximum access to use mineral nutrients.

Table 4: Effect of biopriming with T. harzianum and graded levels of NPK application on dry matter production $\left(\mathrm{g}\right.$ plant $\left.\mathrm{t}^{-1}\right)$ of red kidney bean

\begin{tabular}{|c|c|c|c|}
\hline Treatment & Vegetative stage & Pod formation & Maturation stage \\
\hline T1:Control & $0.1225 \mathrm{a}$ & $0.123333 \mathrm{c}$ & $1.0175 \mathrm{c}$ \\
\hline T2:RDF & $0.225 \mathrm{a}$ & $0.306667 \mathrm{a}$ & $1.425 \mathrm{a}$ \\
\hline T3: 0\%RDF+Biopriming & $0.1675 \mathrm{abc}$ & $0.206667 \mathrm{bc}$ & $1.1275 \mathrm{bc}$ \\
\hline T4: $80 \%$ RDF+ Biopriming & $0.1875 \mathrm{ab}$ & $0.236667 \mathrm{ab}$ & $1.21 \mathrm{~b}$ \\
\hline T5: $90 \%$ RDF+Biopriming & $0.1925 \mathrm{ab}$ & $0.266667 \mathrm{a}$ & $1.2775 \mathrm{ab}$ \\
\hline T6:Control+Biopriming & $0.1575 \mathrm{bc}$ & $0.19 \mathrm{bc}$ & $1.21 \mathrm{~b}$ \\
\hline
\end{tabular}

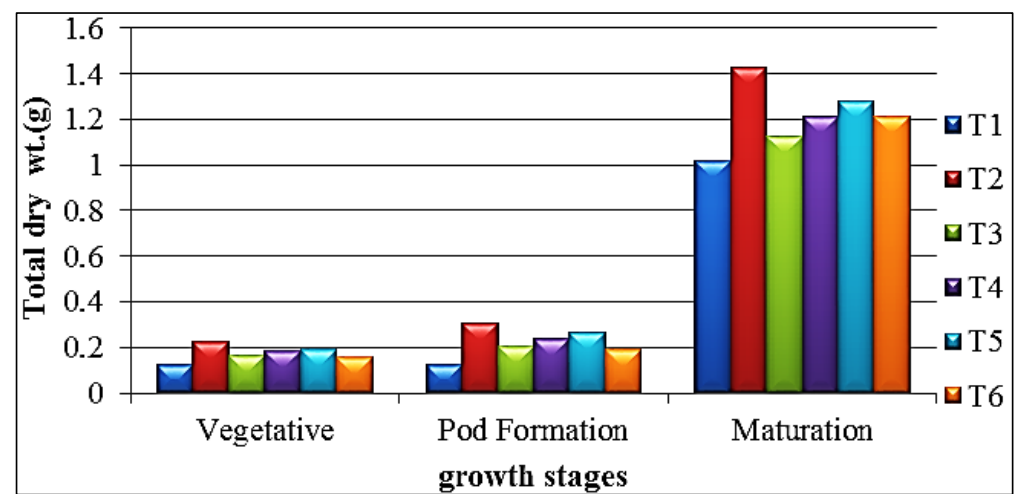

Fig 3: Effects of biopriming with T. harzianum and graded levels of $\mathrm{N}$ application on DMP $\left(\mathrm{g} \mathrm{plant}^{-1}\right)$ of red kidney bean at different growth stages

$\sim 1848 \sim$ 
It may also be ascribed due to adequate supply of nutrients due to mineralization of nutrients by increased population of Trichoderma harzianum. Significant increase in dry matter of tomato plant by the combined use of biofertilizer and N: P: K (Molla et al., 2012) ${ }^{[7]}$. None of the interaction was found significant in this respect during the present experimentation. Trichoderma spp. enhancing plant growth has been reported in several crop plants and has been attributed to auxin (Contreras-Cornejo et al., 2009) "3]. Besides, nutrient acquisition is improved enhancing indirect growth promotion.

\section{Conclusion}

The research data supports the points that biopriming of the crop with Trichoderma harzianum improved the yield, plant height and dry matter production of red kidney bean. This happens because of the fact that the fungus produces plant growth regulators such as auxin and other volatile organic compounds which results in.

\section{Acknowledgements}

Authors thank to Head, Department of Soil Science and Agricultural Chemistry, Institute of Agricultural Sciences, Banaras Hindu University, Varanasi for providing the necessary facility to conduct this experiment and are also thankful to Ministry of Minority Affairs for the post-matric scholarship during the present investigation.

\section{References}

1. Anonymous. FAO Production Year Book. 2003; 56:109110.

2. Ashraf M, Foolad MR. pre-sowing seed treatment-a shotgun approach to improve germination, plant growth, and crop yield under saline and non-saline conditions. Advances in Agronomy, 2005. DOI: 10.1016/S00652113(05) 88006-X.

3. Contreras-Cornejo HA, Macías-Rodríguez L, CortésPenagos C, López-Bucio J. Trichoderma virens, a plant beneficial fungus, enhances biomass production and promotes lateral root growth through an auxin-dependent mechanism in Arabidopsis. Plant Physiology. 2009; 149:1579-1592.

4. Gepts P, Bliss FA. Dissemination pathways of common bean (Phaseolus vulgaris, Fabaceae) deduced from phaseolin electrophoretic variability. II. Europe and Africa. Econ. Bot. 1988; 42:86-104.

5. Kumar V, Shahid M, Singh A, Srivastava M, Mishra A, Srivastava YK et al. A. Effect of Biopriming with Biocontrol Agents Trichoderma harzianum (Th. Azad) and Trichoderma viride (01pp) on Chickpea Genotype (Radhey) J Plant Pathol Microb. 2014; 5:6.

6. Kumar V, Sharma S, Sharma AK, Kumar M, Sharma S, Malik S et al. Genetic diversity in Indian common bean (Phaseolus vulgaris L.) using random amplified polymorphic DNA markers. Physiol. Mol. Biol. Plants. 2008; 14(4):383-387.

7. Molla AH, Haque $M$, Haque A, Ilias GNM. Trichoderma-Enriched Biofertilizer Enhances Production and Nutritional Quality of Tomato (Lycopersicon esculentum Mill.) and Minimizes NPK Fertilizer Use. Agricultural Research. 2012; 1(3):265-272.

8. Moreno CA, Castillo F, Gonza'lez A, Bernal D, Jaimes $\mathrm{Y}$, Chaparro $\mathrm{M}$ et al. Biological and molecular characterization of the response of tomato plants treated with Trichoderma koningiopsis. Physiological and Molecular Plant Pathology. 2009; 74:111-120.
9. Ousley MA, Lynch JM, Whipps JM. Effect of Trichoderrna on Plant Growth: A Balance between Inhibition and Growth Promotion. Microb Ecol. 1993; 26:277-285.

10. Smith VL. Enhancement of snap bean emergence by Gliocladium virens. HortScience. 1996; 31:984-985.

11. Vinale F, Sivasithamparam K, Ghisalberti EL, Marra R, Barbetti MJ, Li $\mathrm{H}$ et al. A novel role for Trichoderma secondary metabolites in the interactions with plants. Physiological and Molecular Plant Pathology. 2008; 72(1-3):80-86.

12. Warren JE, Bennett MA. Seed hydration using the drum priming system. Hort Sci. 1997; 32:1220-1221.

13. Yadav SK, Dave A, Sarkar A, Singh HB, Sarma BK. Coinoculated Biopriming with Trichoderma, Pseudomonas and Rhizobium Improves Crop Growth in Cicer arietinum and Phaseolus vulgaris. International Journal of Agriculture, Environment \& Biotechnology. 2013; 6(2):255-259.

14. Yobo KS, Laing MD, Hunter CH. Effects of Single and Dual Applications of Selected Trichoderma and Bacillus Isolates on Performance of Dry Bean Seedlings Grown in Composted Pine Bark Growth Medium under Shade house Conditions. Journal of Plant Nutrition. 2009; 32:1271-1289.

15. Zeven AC. The introduction of the common bean (Phaseolus vulgaris L.) into Western Europe and the phenotypic variation of dry beans collected in The Netherlands in 1946. Euphytica. 1997; 94:319-328.

16. Geraldine AM, Lopes FAC, Carvalho DDC, Barbosa ET, Rodrigues AR, Brandão RS et al. Cell wall-degrading enzymes and parasitism of sclerotia are key factors on field biocontrol of white mold by Trichoderma spp. Biol. Control. 2013; 67:308-316.

17. Verma JP, Yadav J, Tiwari KN, Jaiswal DK. Evaluation of plant growth promoting activities of microbial strains and their effect on growth and yield of chickpea (Cicer arietinum L.) in India. Soil Biol. Biochem. 2014; 70:3337. 